\title{
Sea cucumber (Aspidochirotida) community, distribution and habitat utilization on the reefs of Mayotte, Western Indian Ocean
}

\author{
Hampus Eriksson ${ }^{1,2, *}$, Maria Byrne ${ }^{2}$, Maricela de la Torre-Castro ${ }^{1,3}$ \\ ${ }^{1}$ Department of Systems Ecology, Stockholm University, 10691 Stockholm, Sweden \\ ${ }^{2}$ Schools of Medical and Biological Sciences, University of Sydney, New South Wales 2006, Australia \\ ${ }^{3}$ Stockholm Resilience Centre, Stockholm University, 10691 Stockholm, Sweden
}

\begin{abstract}
The tropical sea cucumber (Aspidochirotida) fishery for the lucrative Asian driedseafood trade is a multi-species fishery with little ecological knowledge. To improve ecological understanding of the targeted species, the reefs of Mayotte, Western Indian Ocean, were surveyed to document the distribution, species assemblage and habitat utilization of commercial sea cucumbers. This is one of the few reef areas in the region protected from fishing, thus providing an important and unique opportunity to investigate sea cucumber ecology. Twenty-two species were observed. The medium-value Bohadschia atra and the high-value Holothuria nobilis were the most abundant species. Species distribution varied but the density was generally similar across areas and habitats. Multivariate analysis (ANOSIM) indicated that the community was similar between surveyed areas and reef habitats. Diversity was lower in one of the surveyed areas and in the ocean-facing barrier reef habitat. Habitat complexity was not a significant driver of diversity or abundance. A principal component analysis showed that the 6 most common species (B. atra, Holothuria atra, H. fuscopunctata, $H$. nobilis and Thelenota ananas) were associated with different substrate types. Clustering these species according to substrate variables indicated both habitat utilization overlap and segregation among species, valuable information for spatial planning of fisheries management and conservation. Although unique species were observed in some areas, the present study shows that, at a large spatial scale, the unfished reefs in Mayotte consist of similar commercial sea cucumber communities, an important baseline finding.
\end{abstract}

KEY WORDS: Coral reefs · Bêche-de-mer - Trepang · Habitat - Ecosystem-based management · Fisheries management $\cdot$ Tropical seascape

Resale or republication not permitted without written consent of the publisher

\section{INTRODUCTION}

Characterisation of spatial distribution patterns of commercial species is imperative for informed invertebrate fisheries management (Perry et al. 1999). This is also a pre-requisite for identification of protected areas, spatial planning in ecosystem-based management, designing surveys and understanding ecological interactions (Andrew \& Mapstone 1987, Nagelkerken et al. 2000, Sale et al. 2005, Crowder \& Norse 2008, Purcell et al. in press). Sea cucumbers
(Holothuroidea; Aspidochirotida) are commonly harvested in tropical coastal waters for the dried body wall product marketed as bêche-de-mer or trepang in Asian markets (Conand \& Byrne 1993). Bêche-de-mer is produced from around 40 species that are heavily fished throughout the Indo-Pacific, most commonly in under-managed fisheries, despite significant knowledge gaps regarding their ecology (e.g. Uthicke \& Benzie 2000, Purcell 2010, Dissanyake \& Stefansson 2012). The paucity of ecological understanding is a major barrier for management of 
bêche-de-mer resources (Purcell 2010). Although recent research suggests that their presence is important for the productivity in seagrass beds (Wolkenhauer et al. 2010) and in the $\mathrm{CaCO}_{3}$ balance of coral reefs (Schneider et al. 2011), our knowledge of the ecological impact of removal of these conspicuous invertebrates through commercial harvest is poor.

Understanding of the resource-habitat link for the tropical sea cucumber fishery is complicated because it is a diverse multi-species fishery. Some species' tend to occur in aggregations, and their distribution may be influenced by biotic relationships or sediment characteristics (e.g. grain size, organic content) (Conand 1989, Conand \& Chardy 1985, Uthicke \& Karez 1999, Tuya et al. 2006, Shiell \& Knott 2010, Slater \& Jeffs 2010, Dissanyake \& Stefansson 2012). Distribution can also be influenced by other habitat variables such as shelter (Shiell \& Knott 2008). In addition, many species seem to utilize different habitats across stages of their life-history (Byrne et al. 2004, Shiell 2004), a common feature of marine species (Gillanders et al. 2003). For improved planning and management of the sea cucumber fishery it is essential to improve understanding of spatial distribution and habitat utilization of target species.

Since Conand's (1989) studies of the distribution and habitat utilization of sea cucumber communities in New Caledonia, studies at the coastal seascape scale have been scarce, despite sea cucumbers economic importance as bêche-de-mer resources. Broad distribution patterns of common commercial species are often described using general geomorphological habitat features (e.g. Desurmont 2003), and descriptive faunal surveys have been undertaken in the Western Indian Ocean (WIO) (e.g. Conand \& Mangion 2002, 2007, Samyn \& Tallon 2005, Samyn et al. 2006, Mulochau \& Conand 2008). Single-species studies focussing on habitat preference are available for common (e.g. Holothuria atra; Uthicke 1999, Dissanyake \& Stefansson 2012) and high-value species (e.g. Holothuria whitmaei; Uthicke \& Benzie 2000, Shiell \& Uthicke 2006, Shiell \& Knott 2010) or species identified for aquaculture (e.g. Holothuria scabra; Hamel et al. 2001). However, whole community studies or in-depth studies on spatial distribution patterns and habitat utilization for many of the commercial holothurians are rare (e.g. Conand \& Chardy 1985, Bellchambers et al. 2011). This is a major knowledge gap in aspidochirotid ecology in the IndoPacific, where aspidochirotids are a conspicuous component of reef ecosystems.

In the present study, the commercial sea cucumber community around the island of Mayotte in the Co- moros Archipelago, WIO, was mapped, and distribution patterns were analysed using data obtained by manta tow, a survey method applicable to fisheries management teams (Friedman et al. 2008). Historical records suggest that Chinese communities employed fishers in the archipelago to harvest sea cucumbers for export as bêche-de-mer as early as 1916 (MAD 1916). However, the fishery appears to have remained inactive for decades until the mid-1990s when Mayotte experienced a period of unregulated harvest (Pouget 2004). In 2003 commercial sea cucumber species were common on the main islands' fringing reefs (Pouget 2005). The fishery was closed in 2004 (Prefecture de Mayotte 2004). The Comoros Archipelago supports a diverse assemblage of commercial holothurian species (Conand et al. 2005, Samyn et al. 2005, 2006). Mayotte is one of the few large reef systems in the WIO protected from commercial fishing. It is a French department that has, relative to other areas in the region, a high capacity for management enforcement. Thus, this reef system presents an important opportunity for documenting ecological data not available for other reefs in the region due to chronic overfishing (e.g. Conand \& Muthiga 2007, Conand 2008, Eriksson et al. 2010).

Here we investigated the commercial sea cucumber community in 5 areas around the island of Mayotte. We hypothesised that we would not find a difference in community composition between areas of similar habitat categories. To address this hypothesis we examined whole community composition and diversity between 5 surveyed areas and 3 defined habitat categories within these areas. The hypothesis that complex habitats in the reefs of Mayotte would support more diverse and abundant sea cucumber fauna was addressed, as this relationship has been demonstrated for fish communities (Gratwicke \& Speight 2005, Wilson et al. 2007). We also analysed distribution patterns in relation to substrate variables for the 6 most commonly observed species.

\section{MATERIALS AND METHODS}

\section{Survey location and sites}

Mayotte $\left(12^{\circ} 50^{\prime} 35^{\prime \prime} \mathrm{S}, 45^{\circ} 8^{\prime} 18^{\prime \prime} \mathrm{E}\right)$ is located in the Comoros Archipelago on the border between the biogeographic zones of the Somali Basin and the Mozambique Channel in the Western Indian Ocean (Fig. 1). Mayotte has narrow fringing reefs with small near-shore lagoon areas. The main island is enclosed by an extensive barrier reef with a deep lagoon 


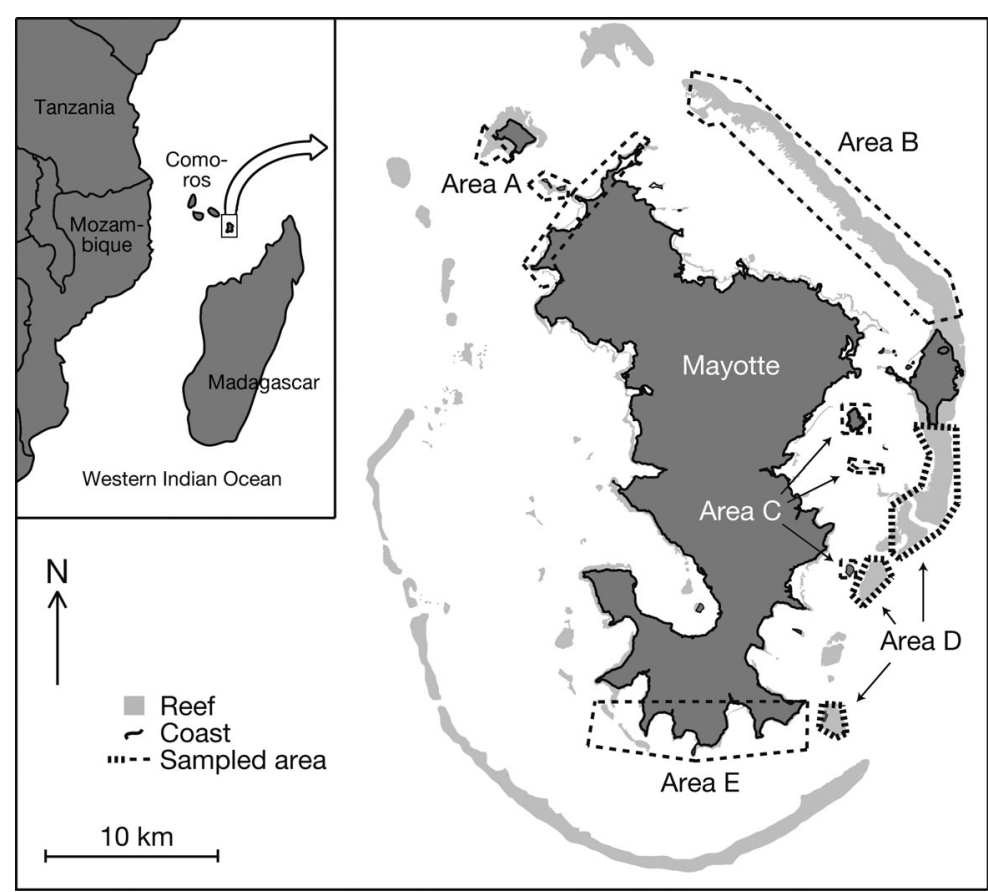

Fig. 1. Mayotte $\left(12^{\circ} 50^{\prime} 35^{\prime \prime} \mathrm{S}, 45^{\circ} 8^{\prime} 18^{\prime \prime} \mathrm{E}\right)$ and the surveyed areas. Note that Area D is illustrated with a heavier dashed line to distinguish from nearby Area C (inner islands)

between the fringing and barrier reefs. Commercial sea cucumbers were surveyed in Mayotte from 22 April to 22 June 2010. The sampling design was stratified into 5 geographic areas to investigate the distribution of species (Fig. 1, Table 1). These areas were chosen as they contained contrasting habitats from around the island. The western side of the island could not be surveyed for logistical reasons.

\section{Survey method}

Fringing and barrier reef zones in Areas A to E were surveyed using the manta board technique (English et al. 2003). This method is suitable for census of large, sedentary conspicuous sea cucumber species (see Uthicke \& Benzie 2000, Purcell et al. 2009, Shiell \& Knott 2010), and is recommended by Friedman et al. (2008) for underwater visual census of commercial sea cucumbers. This method is likely to underestimate the density of cryptic or nocturnal species (e.g. Shiell \& Knott 2008). Consequently, the analysis is limited to the species suitable to census by this method (i.e. large or conspicuous species). The sampling unit was a $300 \times 2 \mathrm{~m}$ transect, following the Reef Fisheries Observatory program at the Secretariat of the Pacific Community (SPC) (Friedman et al. 2011). This rela- tively large unit area covers a mosaic of habitats, referred to as 'blanket manta tows' by Shiell \& Knott (2010). Three coarsely defined habitat types were identified, i.e. fringing reef, inside barrier reef and outside barrier reef, to allow for habitat distribution analysis (Table 2). The distance and speed of the tows were monitored using a handheld GPS (Garmin ${ }^{\circledR} 60$ ) by staff in the boat. Sea cucumber counts were recorded on a data sheet mounted on the manta board. Upon completion of each transect a range of habitat variables was recorded to describe the environment (Table 3). The habitat variables included descriptions of the physical habitat, percentage area of substrates and percentage cover of seagrass.

\section{Data presentation and statistical analysis}

We used the percentage of manta tows where a species was present as a measure of its occurrence, and calculated the density (no. ind. ha ${ }^{-1}$ ) in tows where a species was observed. The occurrence and density was calculated for each surveyed area and habitat category. The

Table 1. Description of surveyed reef sites (see Fig. 1) and the sampling effort (n)

\begin{tabular}{|llc|}
\hline Area & \multicolumn{1}{c}{ Description } \\
\hline A $\quad \begin{array}{l}\text { North facing fringing reef: } \\
\text { this area is commonly exposed } \\
\text { to northern swells as there is no } \\
\text { protective barrier reef } \\
\text { B } \quad \begin{array}{l}\text { Northeast facing barrier reef: } \\
\text { expansive barrier reef area on a NE aspect }\end{array}\end{array}$ & 60 \\
C $\quad \begin{array}{l}\text { Lagoon island fringing reef: } \\
\text { fringing reefs on lagoon islands generally }\end{array}$ & 24 \\
& $\begin{array}{l}\text { with high influence of land and nearby } \\
\text { capital Mamoudzou }\end{array}$ \\
D $\quad \begin{array}{l}\text { Southeast facing barrier reef: } \\
\text { expansive barrier reef area on a SE aspect } \\
\text { broken up by deep channels }\end{array}$ & $60^{\mathrm{a}}$ \\
E $\begin{array}{l}\text { South facing fringing reef with a stretch } \\
\text { of detached barrier reef: this area is } \\
\text { more protected from swell than Area A } \\
\text { is by the adjacent barrier reef. }\end{array}$ & 60 \\
$\begin{array}{l}\text { In addition, there are some areas with river } \\
\text { runoff and mangroves }\end{array}$ & \\
a30 inside and 30 outside
\end{tabular}


Table 2. Definition of stratified sampling habitats

\begin{tabular}{|ll|}
\hline Habitat & Definition \\
\hline Fringing reef & $\begin{array}{l}\text { Near-shore reef following the island's } \\
\text { contour. This habitat type was sampled } \\
\text { across the reef crest and reef flat areas, } \\
1-4 \text { m deep }\end{array}$ \\
Inside & $\begin{array}{l}\text { Lagoon-facing barrier reef area, } \\
\text { benerally protected from swell impact. }\end{array}$ \\
& $\begin{array}{l}\text { Complex coral bommies and areas of soft } \\
\text { sediment or rubble and boulders in } \\
\text { between. Occasionally seagrass cover } \\
\text { observed, 1-5 m deep }\end{array}$ \\
Outside & $\begin{array}{l}\text { Ocean-facing barrier reef area exposed } \\
\text { to high energy and swells. Mostly hard } \\
\text { barrier reef } \\
\text { topographic (boulders and pavement) } \\
\text { complexity live coral growth, 1-8 m deep }\end{array}$ \\
&
\end{tabular}

Table 3. Recorded habitat variables and a brief description of how they are estimated

\begin{tabular}{|c|c|}
\hline Variable & Description \\
\hline \multicolumn{2}{|l|}{ Abiotic variables: } \\
\hline Relief & $\begin{array}{l}\text { Visual topographic estimate of the substratum } \\
\text { in each transect. Ranked } 1-5 ; 1 \text { is flat and } 5 \text { is } \\
\text { an undulating habitat }\end{array}$ \\
\hline Complexity & $\begin{array}{l}\text { Visual estimate of the substrate variation and } \\
\text { complexity in each transect. Ranked } 1-5 ; 1 \text { is } \\
\text { simple and } 5 \text { is a highly complex habitat }\end{array}$ \\
\hline Ocean influence & $\begin{array}{l}\text { Estimated mix of ocean- and land-influenced water. } \\
\text { Ranked } 1-5 ; 1 \text { is mostly land influenced and } \\
5 \text { is clear water with high ocean influence }\end{array}$ \\
\hline Depth & Visual estimate of mean depth of manta tow transect \\
\hline Substrate: & $\begin{array}{l}\text { Visual estimate of percentage of each substrate } \\
\text { variable. The sum of all substrate variables } \\
\text { must add up to } 100 \%\end{array}$ \\
\hline$\%$ Soft & Mud, sand, coarse sand \\
\hline$\%$ Rubble & $<25 \mathrm{~cm}$ fragments of coral, stone, or debris \\
\hline$\%$ Boulders & $>30 \mathrm{~cm}$ pieces of detached coral stone and limestone \\
\hline $\begin{array}{l}\% \text { Consolidated } \\
\text { rubble }\end{array}$ & $\begin{array}{l}<30 \mathrm{~cm} \text { cemented pieces of coral stone } \\
\text { and limestone }\end{array}$ \\
\hline$\%$ Pavement & Solid flat stone (generally limestone) benthos \\
\hline$\%$ Live coral & Live hard coral \\
\hline$\%$ Dead coral & Coral that has recently died (covered with turf algae) \\
\hline Cover: & $\begin{array}{l}\text { Visual estimate of percentage substrate cover- } \\
\text { does not have to add up to } 100 \%\end{array}$ \\
\hline$\%$ Seagrass & Visual estimate of area with seagrass cover \\
\hline
\end{tabular}

ananas). In addition, the density of these species was compared between areas and habitat categories. The density data deviated from normal distribution, as determined by Bartlett's test, so a Kruskal-Wallis test was chosen, a suitable non-parametric alternative to ANOVA (Quinn \& Keough 2002). For species indicating significant difference in overall density a post hoc pairwise comparison was done using Wilcoxon's signed-rank test, which is a rank-based, non-parametric test (Quinn \& Keough 2002), with Bonferroni correction. All analyses were performed using R.2.9.2 (R Development Core Team 2008).

Data determined for the sea cucumber community (diversity and abundance) were analysed and illustrated by calculating the Bray-Curtis dissimilarity matrix using the VEGAN package in $\mathrm{R}$ (Oksanen et al. 2011), and non-metric multidimensional (nMDS) scaling was performed on this matrix. Data were fourth-root transformed to reduce dispersion (Field et al. 1982). Confidence intervals (95\%) were applied to the ordination. Significance testing for difference in community composition between the surveyed areas and habitat categories was performed using ANOSIM with permutations in the VEGAN package in $\mathrm{R}$ as outlined by Oksanen et al. (2011). In addition, the relationship between species diversity and abundance with habitat complexity (scored 1 to 5) was investigated using a linear regression analysis.

Habitat variables associated with the distribution of the 6 most common species were used to assess species habitat overlap or segregation. We used the mean percentage or score of each of the recorded habitat variables determined for each species. The means were weighted according to species abundance, increasing the weight of variables in transects where a particular species was abundant. Principal component analysis (PCA) was used to identify and visualize the

difference in percentage of observations between area and habitat categories was tested with a pairwise Fisher's exact test, which is suitable for categorical data with small sample sizes (Dixon \& Massey 1969), with Bonferroni correction for the 6 most common species (e.g. Bohadschia atra, Holothuria atra, H. fuscopunctata, H. nobilis, Stichopus chloronotus, Thelenota habitat variables explaining species-specific distribution using the VEGAN package in $\mathrm{R}$ (Oksanen 2009). The Euclidean distance was calculated for habitat variables at a species level. Average linking was applied to the distance matrix; species were then clustered in a dendrogram following their dissimilarity in recorded habitat preference. 


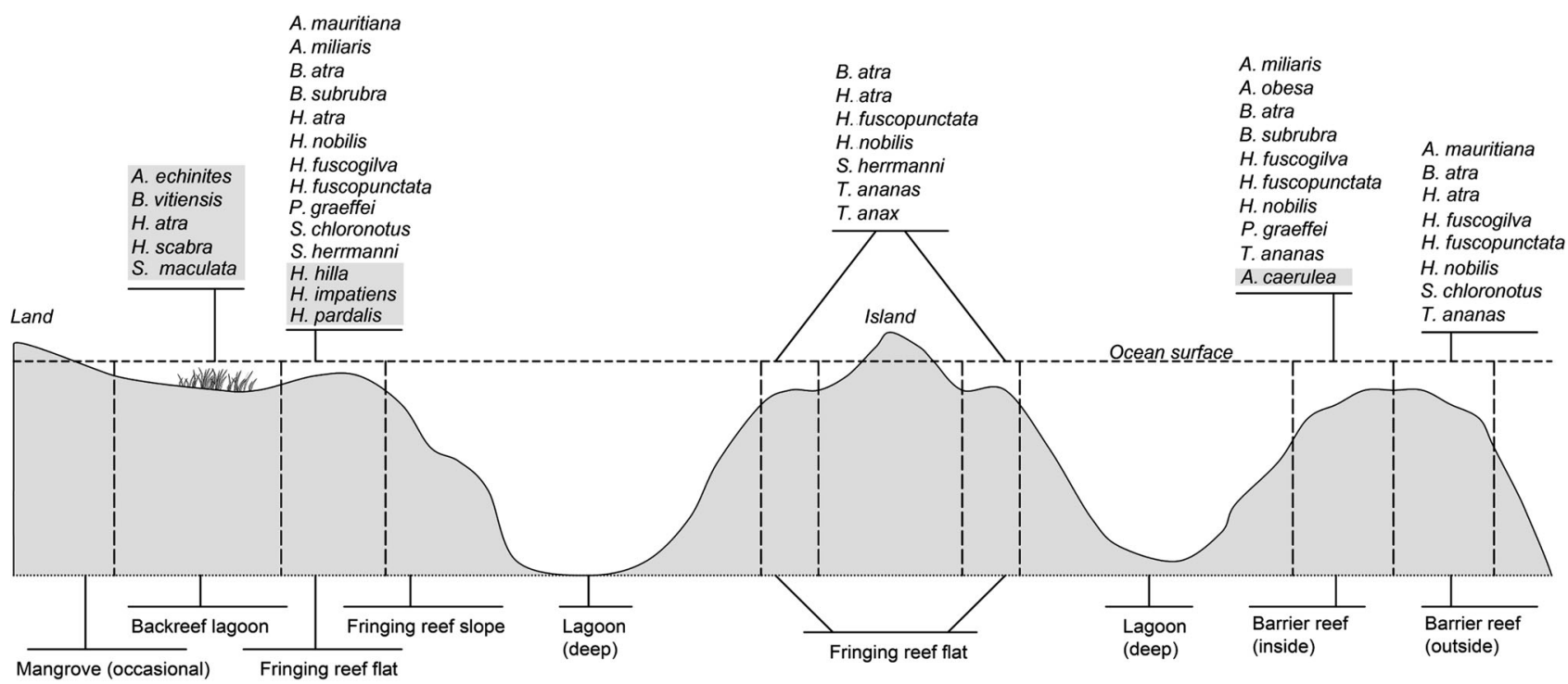

Fig. 2. General seascape in Mayotte with coarse geomorphological descriptions of locations where recorded species were found. Note that the back reef lagoon was not surveyed with manta tows. The species detailed in shaded areas were observed outside manta tows and not further detailed in this study. See Table 4 for full species' names

\section{RESULTS}

\section{The assemblage and its spatial distribution}

A total of 14 sea cucumber species were observed in manta tows with an additional 8 species observed outside of manta tows (Fig. 2, Table 4). Bohadschia atra and Holothuria nobilis were the most common species. These species, together with Thelenota ananas and Holothuria fuscopunctata were the only species observed in all areas. In contrast, other species were only observed in $\leq 3$ survey areas. Stichopus chloronotus, for example, was only recorded in Areas $A$ and $B$, but at high abundance in an aggregated distribution. Some species were most common in certain areas or habitat categories. For example, B. atra was most common in fringing reef habitat ( $p=0.00$ to 0.05 ), while $H$. nobilis was more common in outside barrier reef habitat $(\mathrm{p}=0.02$ to 0.05$)$. Similarly, $H$. atra showed a preference for fringing reefs $(\mathrm{p}<0.00)$. Notably, $T$. anax was only observed on the lagoon islands' fringing reefs in Area C.

There was a significant difference in density between areas for Thele-
Table 4. Sea cucumber species distribution in the Mayotte reef system analysed with the species-specific percentage of manta tows, in which the species were recorded. Species are listed in order of total occurrence. Bold print indicates the area (A to E, see Fig. 1) or habitat category (FR: fringing reef; IBR: inside barrier reef; OBR: outside barrier reef) with the highest occurrence for the 6 most common species. More than 1 bold number per species indicates that those numbers are similar and significantly higher $(\mathrm{p} \leq 0.05)$ than those not indicated in bold. An underscored number is significantly higher than a bold number. Other species observed outside of manta tows are also listed, with notes on their habitat

\begin{tabular}{|c|c|c|c|c|c|c|c|c|c|}
\hline \multirow[t]{2}{*}{ Species } & & \multicolumn{5}{|c|}{ Area } & \multicolumn{3}{|c|}{ Habitat category } \\
\hline & urrence & A & B & $\mathrm{C}$ & $\mathrm{D}$ & $\mathrm{E}$ & FR & IBR & OBR \\
\hline Bohadschia atra & 38 & 42 & 23 & 33 & 25 & 67 & 50 & 33 & 24 \\
\hline Holothuria nobilis & 32 & 40 & 35 & 8 & 43 & 20 & 28 & 27 & 44 \\
\hline Thelenota ananas & 16 & 12 & 18 & 17 & $\underline{27}$ & 8 & 10 & 21 & 24 \\
\hline Holothuira atra & 14 & 27 & 2 & & 3 & 28 & 25 & 3 & 3 \\
\hline Stichopus chloronotus & 9 & 3 & 15 & & & & 13 & 2 & 11 \\
\hline Holothuria fuscopunctata & 7 & 7 & 2 & 17 & 17 & 2 & 5 & 14 & 4 \\
\hline Actinopyga mauritiana & 5 & & 15 & & & 2 & 4 & & 13 \\
\hline Holothuria fuscogilva & 3 & & 3 & & 8 & & & 8 & 3 \\
\hline Bohadschia subrubra & 3 & 8 & 2 & & 2 & & 4 & 3 & \\
\hline Actinopyga miliaris & 2 & & 2 & & 5 & & & 6 & \\
\hline Stichopus herrmanni & 2 & 2 & & 17 & & & 4 & & \\
\hline Thelenota anax & 1 & & & 13 & & & 2 & & \\
\hline Actinopyga obesa & 1 & & & & 3 & & & 3 & \\
\hline Pearsonothuria graeffei & 1 & & & 4 & 2 & & 1 & 2 & \\
\hline \multicolumn{10}{|l|}{ Other observed species } \\
\hline Actinopuga caerulea & \multicolumn{9}{|c|}{$\begin{array}{l}\text { Observed on reef at ca. } 10 \mathrm{~m} \text { depth } \\
\text { while scuba diving }\end{array}$} \\
\hline Actinopyga echinites & \multicolumn{9}{|c|}{ Observed during night snorkel in back reef } \\
\hline Bohadschia vitiensis & \multicolumn{9}{|c|}{ Observed in soft benthic habitat } \\
\hline Holothuria hilla & \multicolumn{9}{|c|}{ Observed under rubble on reef flat } \\
\hline Holothuria impatiens & \multicolumn{9}{|c|}{ Observed under rubble on reef flat } \\
\hline Holothuria pardalis & \multicolumn{9}{|c|}{ Observed under rubble on reef flat } \\
\hline Holothuria scabra & \multicolumn{9}{|c|}{ Observed in soft benthic habitat } \\
\hline Synapta maculata & \multicolumn{9}{|c|}{ Observed in seagrass habitat } \\
\hline
\end{tabular}



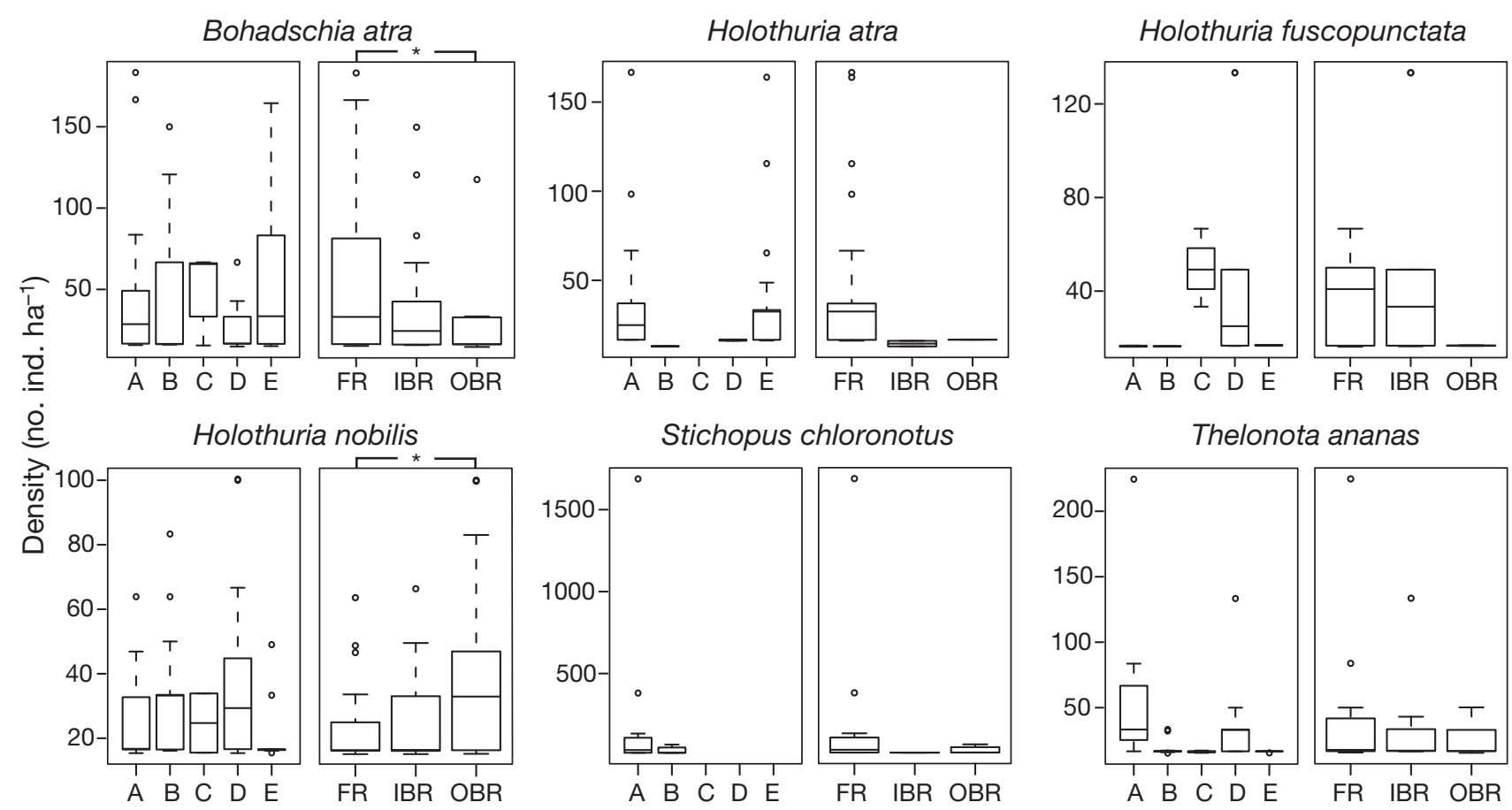

Fig. 3. Density of the 6 most commonly recorded sea cucumber species in manta tows in 1 or more observation periods ( $\mathrm{n} \geq 1$ ) in Mayotte reef system. Asterisks represent significant differences tested using Wilcoxon's pairwise test following a KruskalWallis test for overall significance. Areas are denominated by their assigned letter (A-E) and habitat category by the abbreviations -FR: fringing reef; IBR: inside barrier reef; OBR: outside barrier reef

nota ananas $(H=18.66, \mathrm{df}=2, \mathrm{p}<0.00)$, but no pairwise difference was found ( $\mathrm{p} \geq 0.07$ ), indicating unbalanced data for pairwise comparisons over the 5 groups. There was a significant relationship between density and habitat category for Bohadschia atra $(H=$ $7.44, \mathrm{df}=2, \mathrm{p}=0.02)$ and Holothuria nobilis $(H=6.35$, $\mathrm{df}=2, \mathrm{p}=0.04$ ) (Fig. 3). A Wilcoxon pairwise test with Bonferroni correction showed that the density of $B$. atra was higher on fringing reefs than outside barrier reef areas $(p=0.03)$, and the density of $H$. nobilis was higher in outside barrier reef areas than on fringing reefs $(p=0.04)$.

The ordination analysis illustrated that community structure between the 5 areas (Fig. 4A) and 3 habitat categories (Fig. 4B) were similar. There was a small difference in communities between the surveyed areas (ANOSIM: $\mathrm{R}=0.17, \mathrm{p}<0.00$ ). Narrower elliptic confidence interval of the fringing reef Area $E$ in ordination space indicated a more homogenous community structure and a slight difference in community, in particular from the barrier reef Areas B and D (Fig. 4A). The communities were also similar between habitat categories (ANOSIM: $\mathrm{R}=0.06$, $\mathrm{p}=0.01)$; however, the barrier reef habitat showed a slight dissimilarity in community composition from the lagoon-facing fringing reefs and inside barrier reef areas, as seen in the separation in the elliptic confidence intervals in ordination space (Fig. 4B).

The lowest sea cucumber diversity (6 species) was recorded in the southern fringing reef Area E (Table 4). There was a higher diversity of species in the lagoon-facing habitats (fringing reefs and inside barrier reefs) than in the ocean-facing barrier reef habitat (6 species) (Table 4$)$, but there was no relationship between diversity $\left(\mathrm{R}^{2}<0.1, t_{1,268}=5.22\right.$, $\mathrm{p}<0.00)$ or abundance $\left(\mathrm{R}^{2}<0.1, t_{1,268}=3.15, \mathrm{p}<0.00\right)$ and habitat complexity score (Fig. 5).

\section{The common species' habitat utilization}

The plotted axes in the PCAs explain ca. $90 \%$ of the variance in the habitat-species relationships (Fig. 6A). The PCA illustrates how Holothuria atra was found mostly on boulder and rubble type substrates. H. fuscopunctata and Thelenota ananas are separated from the other species in the PCA because they were recorded in manta tows over habitats with finer sand. These 2 species are separated from each other because of the nature of the soft substrate on which they were recorded; $T$. ananas was found in areas with high oceanic influence and at greater 


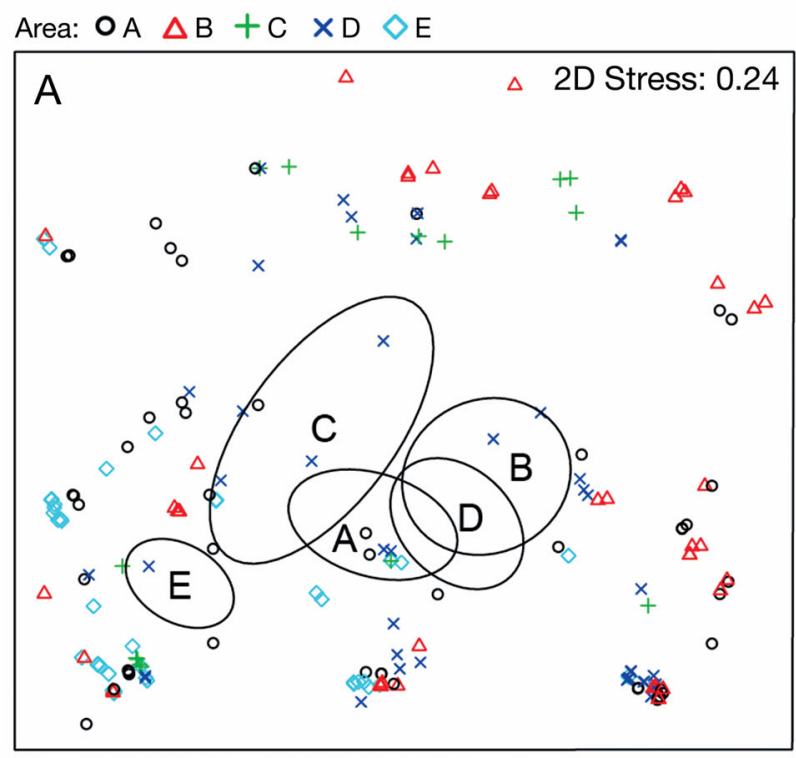
Fringing reef $(\mathrm{FR})+$ Inside barrier reef $(\mathrm{IBR})$
$\triangle$ Outside barrier reef (OBR)

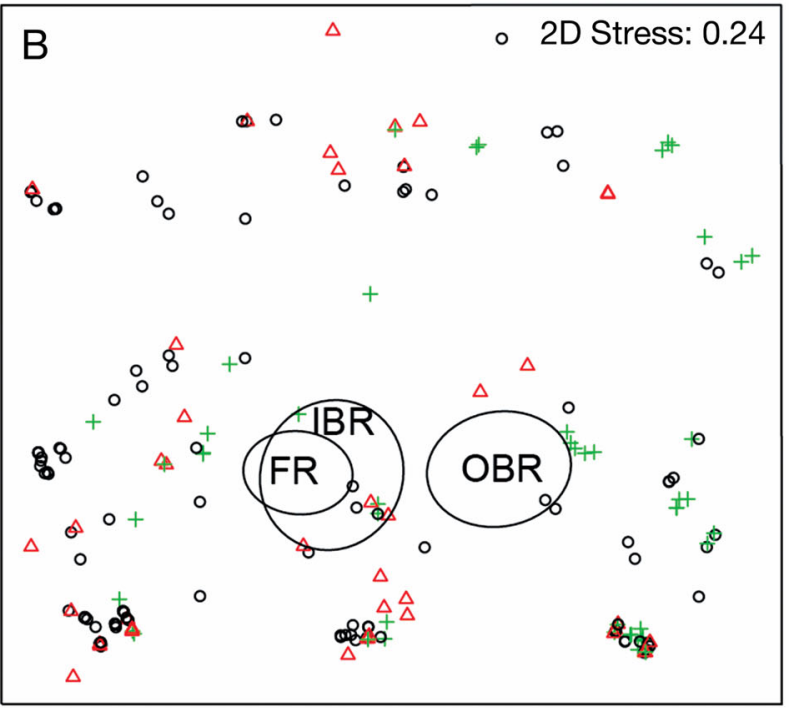

Fig. 4. Ordination plot of commercial sea cucumber community structure in samples from (A) surveyed areas and (B) habitat categories in Mayotte. Data has been ordinated from the Bray-Curtis dissimilarity matrix. Ovals represent the areas of $95 \%$ confidence intervals

depth, while $H$. fuscopunctata was recorded in areas with lower oceanic influence, higher complexity and more soft sediment. $H$. nobilis and Bohadschia atra are clustered due to their preference for harder substrate. Stichopus chloronotus was also most often encountered on pavement substrate. The cluster analysis illustrates the linkages in similarity and dissimilarity in distribution among these species based on their associated habitat variables (Fig. 6B). Three groups were evident in the dendrogram, roughly representing the reef flat area $(B$. atra, $H$. nobilis, $S$. chloronotus), sandy lagoon areas with widespread live coral ( $H$. fuscopunctata, $T$. ananas) and the rubble and boulder substrate back reef area (H. atra).

\section{DISCUSSION}

\section{Distribution of the sea cucumber community}

Most species were observed in $>1$ surveyed area or habitat in the coastal seascape. Although the 6 most

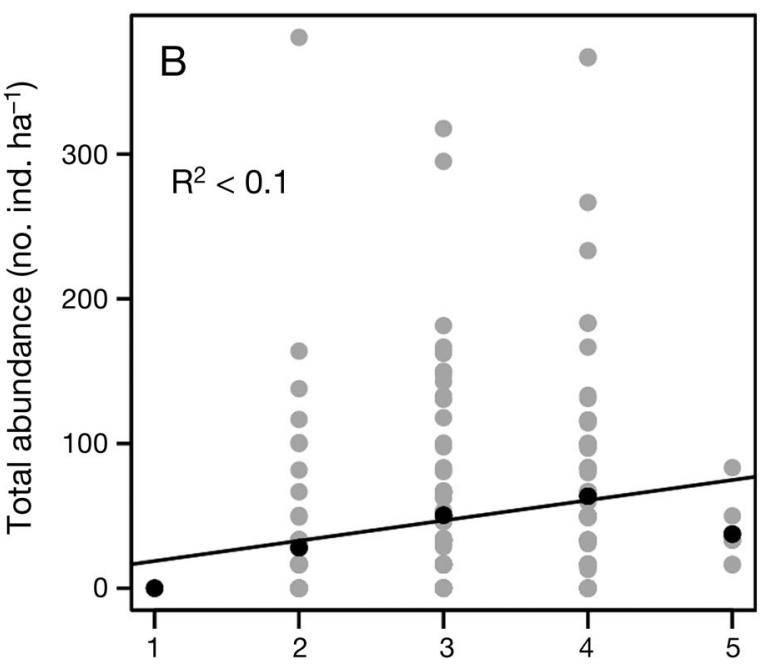

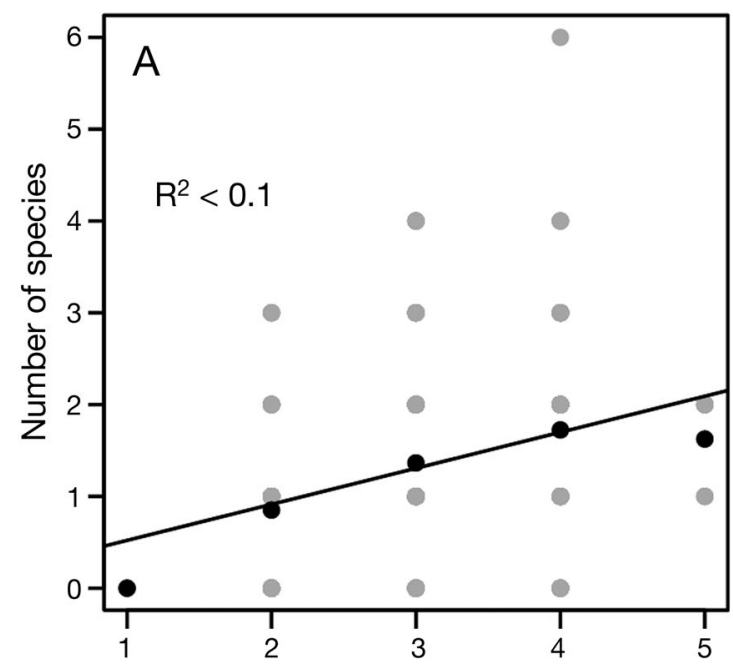

Habitat complexity score

Fig. 5. Correlation between habitat complexity score (1 to 5) and (A) number of observed species and (B) abundance sampled with manta tows in the reefs of Mayotte. Grey dots are data points; black dots are the mean values. Line is linear correlation 

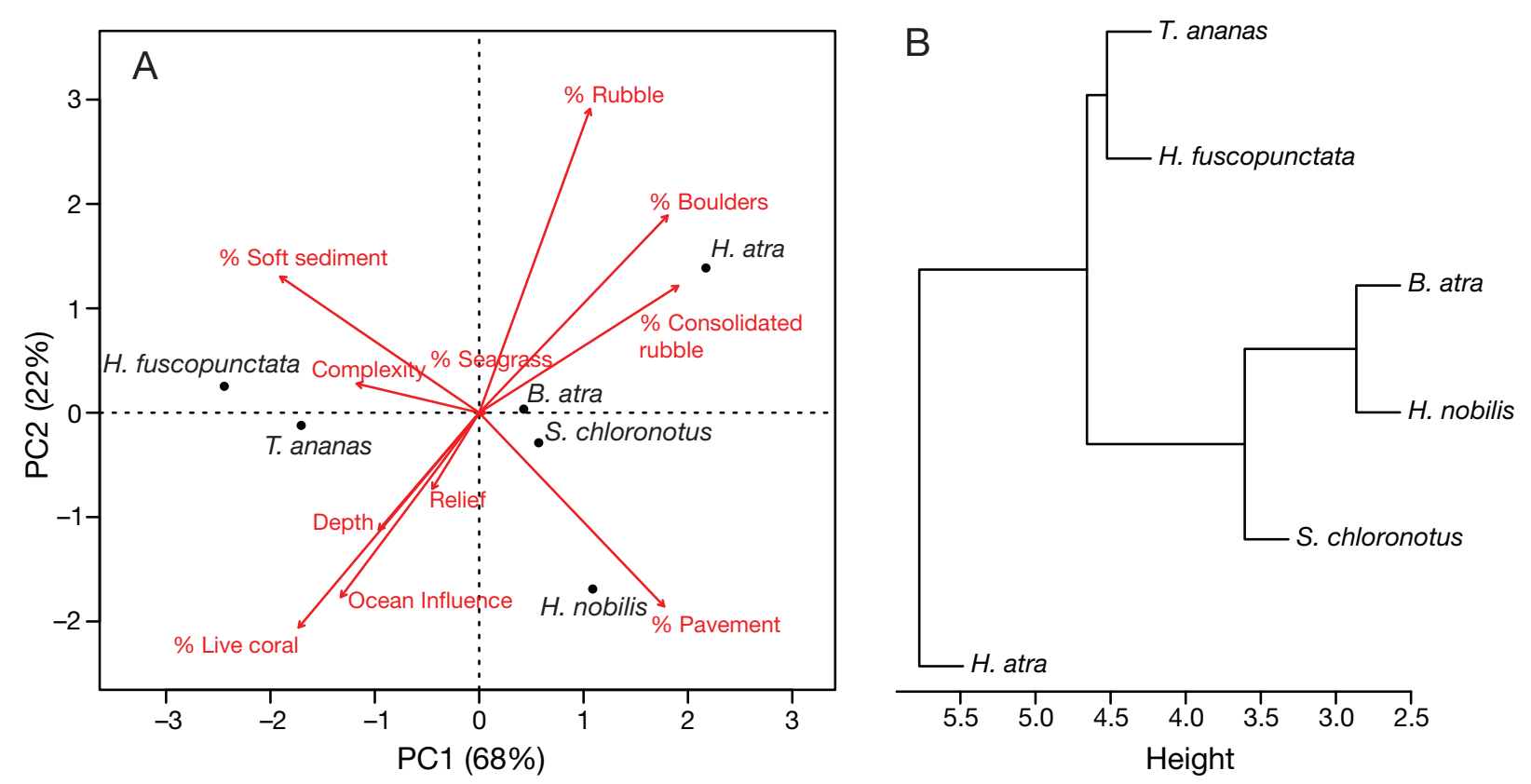

Fig. 6. (A) Principal components analysis of the recorded habitat variables (see Table 3) and the relative location of sampled species (see Table 4 for full species' names). Habitat variables have been weighted according to abundance. (B) Cluster analysis using average linkage (between species-specific habitat variables) of the distribution of 6 commercial sea cucumbers in Mayotte. 'Height' on the $x$-axis is the distance between clusters illustrating dissimilarity. Habitat variables have been weighted according to abundance

common species were observed in significantly more manta tows in certain areas or habitat categories, they were widely distributed. This is further illustrated by the community composition, where all areas and habitat categories had manta tow data with similar, or even identical, observations. The PCA shows that some species were strongly associated with single or a few habitat variables, such as Holothuria nobilis (e.g. pavement substrate), while others were less clearly associated with specific habitat variables (e.g. Bohadschia atra). The reef habitat was heterogeneous, as typical of ocean systems (Crowder \& Norse 2008), and this influenced the spatially complex patchy distribution of the sea cucumbers throughout the seascape in Mayotte. Patchy distribution due to habitat utilization linked to seascape heterogeneity is a general feature of marine assemblages (Boström et al. 2011) and possibly provides an explanation as to why species are found aggregated, as reported by Shiell \& Knott (2010). Population dynamics linked to these patchy animal-habitat associations, for example through connectivity in 'source-sink' relationships, are generally underresearched (Boström et al. 2011) but should be on the research agenda for commercial sea cucumbers as it may affect their ability to recover from fishing and maintain ecosystem functionality.
The species-specific habitats are similar to those observed in a descriptive taxonomic survey in the Comoros by Samyn et al. (2006) and elsewhere in the region (review by Conand 2008). However, Holothuria atra, which is usually found in sandy areas (Bellchambers et al. 2011, Dissanyake \& Stefansson 2012), was found associated with hard reef substrate. This is perhaps explained by the ecology of this species, exhibiting two morphs: a small morph that usually occupies shallow lagoons and a larger morph that usually occupies reef areas (Chao et al. 1994), coupled with the limited area of shallow lagoons in Mayotte. Bohadschia atra and $H$. nobilis were the most common species, and their distribution was the major influence in the homogeneity in community structure between areas. Although B. atra and $H$. nobilis were in the same cluster in the dendrogram, and so exhibited similar habitat variables, they were separated spatially. B. atra was more common in fringing reef habitat than in outside barrier reef habitat; the opposite pattern was evident for $H$. nobilis. The contrasting distribution of these species and the lower diversity (fewer unique species) was the driver of community difference in Area $\mathrm{E}$ and in the oceanfacing barrier reef habitat category noted in ordination space (Fig. 4). Most of the 6 focal species were observed at different frequencies between areas and 
habitats. However, the density was similar across areas and habitat categories (other than the difference noted between fringing reefs and outside barrier reefs for $B$. atra and $H$. nobilis). Hence, while these results support the hypothesis that the sea cucumber community is similar between surveyed reef areas and habitat categories, the results also indicate that there are differences in diversity and distribution, primarily of less abundant species. In a survey in New Caledonia, Purcell et al. (2009) also noted a lower diversity of commercial sea cucumbers on the more exposed ocean-facing side of barrier reefs.

It appears that while areas had a similar sea cucumber community, largely due to similar densities of common species, unique or rare species occurred at a frequency or density too small to signal difference at a community level. This shows the need for visual census for spatial planning of fisheries and demonstrates that unique species should be exempt from harvesting, due to the difficulty in monitoring them and in identifying changes in community size or structure. Among the least common species were Actinopyga obesa, Bohadschia subrubra and Thelenota anax for which no ecological studies exist. Although the abundance of some species may be underestimated by our survey method, this paucity of research supports that exclusion of rare species is also an imperative for conservation of diversity.

\section{Species diversity and abundance}

We did not find a correlation between habitat complexity and diversity or abundance. This result, while not supporting our hypothesis, is intuitive as different species showed preference for different types of substrates and these varied in complexity. The PCA for the 6 most common species indicated that habitat complexity had an influence on the distribution of Holothuria fuscopunctata and Thelenota ananas; however, other species were more strongly associated with particular substrate variables. It appears that habitat complexity only partially explained the increase in diversity and abundance, potentially through a habitat diversity effect or increased area per se (e.g. Johnson et al. 2003) associated with the habitat mosaic of the reef at a larger spatial scale. The highest complexity score was recorded in areas with dense live coral with little sediment, which do not provide suitable feeding habitat for many sea cucumber species, which ingest sand. In addition, the most complex habitat was also more difficult to survey and cryptic or nocturnal species would not be detected.

In a previous holothuroid inventory on the Comoros Archipelago by Samyn et al. (2005), 40 species were recorded, with approximately half of these being commercial aspidochirotids (as identified in a review by Conand 2008). For Mayotte, 27 holothuroids are listed in the survey by Conand et al. (2005), with 20 of these being commercial aspidochirotids. In the present study, we observed 22 of the species listed by Conand et al. (2005). We did not observe the commercially valuable Holothuria lessoni (formerly known as Holothuria scabra versicolor; Massin et al. 2009), which was listed by Conand et al. (2005). This species is typically associated with soft sediment habitats that we did not census.

In Mayotte, commercial high-value species (i.e. Holothuria nobilis, $H$. fuscogilva and Thelenota ananas, as defined by Conand 2008) constituted $27 \%$ of total observations, compared to $1 \%$ in Zanzibar where the fishery is active (Eriksson et al. 2010) and $<3 \%$ in the unfished isolated atoll system of the Cocos (Keeling) Islands (Bellchambers et al. 2011). The most common species, Bohadschia atra, was also noted as common in the sea cucumber appraisal on fringing reefs in Mayotte in 2003 (Pouget 2005). However, the same high density of the high-value species' $H$. nobilis and $T$. ananas, which were target species in the previous fishery, was not observed by Pouget (2005). This may partially be explained by different survey methods and habitats. For example, we established that $H$. nobilis was more abundant on barrier reefs than on fringing reefs, which was the target habitat for the appraisal by Pouget (2005). But it may also indicate a recovery after protection. In contrast, $H$. whitmaei, the Pacific sister species of $H$. nobilis, in Queensland, Australia, did not recover following depletion in 1999, as indicated in re-surveys of fished areas (Uthicke et al. 2004). The mean density of 10 to 20 ind. ha ${ }^{-1}$ for $H$. nobilis in survey areas in Mayotte is similar to published 'natural' densities from the Western Central Pacific (Kinch et al. 2008).

\section{Survey data and applicability}

While survey design should reflect target species ecology (Shiell \& Knott 2010), given the multi-species nature of the fishery, and varying ecology among species, this would be intractable for management teams with limited capacity. The heterogeneous nature of sea cucumber distribution highlights the suitability of manta tows as a broad-scale assessment 
method to characterise the spatial distribution of stocks to inform fisheries management. The manta tow method is not suitable for sampling small species in cryptic habitats or nocturnal species, and our study did not exceed $8 \mathrm{~m}$ in depth. For a more comprehensive picture of the holothurian assemblage, a range of sampling methods would be required to ensure observation of nocturnal, cryptic, or deep-water species. Targeted sampling methods would also be required to build a profile of the size distribution of populations.

There is a trade-off between the effort required to survey expansive areas for sea cucumber habitat and the accuracy of the method for ecological analysis. Moreover, it is challenging to achieve high levels of replication. Using the broad-scale manta tow method is not ideal for stratification into detailed habitat zones associated with reefs. For example, in Mayotte the fringing reef is so narrow that it is practically impossible to stay within any of the commonly defined reef habitats (e.g. back reef, reef flat, reef crest, reef slope and reef front). Here we stratified our sampling at a coarser scale and used specific habitat variables surveyed in parallel with documentation of the sea cucumber assemblage to characterise habitat utilisation. On the other hand, the manta tow method is a powerful approach because it facilitates coverage of large areas so that large-scale patterns important for fisheries management can be derived with confidence.

\section{Contextualizing our findings}

Our approach to determining the distribution and abundance of aspidochirotids in Mayotte analysed patterns that are largely driven by complex and interrelated variables (e.g. physical, ecological, or chemical) that operate at different scales. Thus, we used a diverse suite of habitat variables to avoid a narrow single-variable analysis. This facilitated an ecologically meaningful identification of the habitat variables associated with the 6 most common commercial sea cucumbers in Mayotte. The novel contribution of the present study to our understanding of sea cucumber ecology lies in the fact that our study was undertaken in one of a few large reef areas protected from fishing. The protection effect is illustrated by the abundance of species with high and medium commercial value. Where other studies have contributed with detailed analysis on distribution of single or common species (e.g. Uthicke \& Karez 1999, Dzêroski \& Drumm 2003, Dissanyake \& Stefansson
2012) or on $>1$ species but within similar habitats (e.g. Massin \& Doumen 1986), we have, similarly to Conand \& Chardy (1985) and Conand (1989), attempted to provide a large-scale picture of a sea cucumber community that included commercially valuable species. In addition, we used a survey method applicable to management teams generating an assessment of habitat utilization in relation to substrate variables of several commercially valuable aspidochirotid species. In this context, our study used habitat variables collected using visual estimates, and we acknowledge that distribution for many species is probably driven by variables at a scale not captured in our approach. Recorded variables here may, however, act as proxies for actual drivers (e.g. substrate may be a proxy for food content). The distribution of the sea cucumber assemblage at Mayotte underscores that careful spatial planning of fishing grounds and closed zones is important for ecologically relevant area-fishery management. For example, the cluster analysis indicated that some species could be managed by protection within the same type of habitat. However, protection of a wide range of habitats would be needed to ensure protection of several species. Spatial planning is made difficult by the fact that processes associated with early life-history, such as settlement substrate or juvenile habitat, remain unknown for most species. The underlying processes that drive the distribution, abundance and habitat utilization of commercial sea cucumbers needs to be further studied to assist inclusion of this resource in ecosystem-based management. In particular, research relating to the role of habitats in early life-history is required to map dispersal and the true scales of species-specific habitat utilization and should be a priority for future studies.

Acknowledgements. Thanks for financial and logistic support by Benjamin Esperance at la Direction de l'Agriculture et de la Forêt, and Léonard Durasnel and Said Mohammed at Conseil General de Mayotte. Also thanks to Julien Wickel, Alban Jamon, Didier Frey, Rébecca Guezel and Karani Saindou for field support, to Nils Kautsky for input on the manuscript, and to Jan-Olov Persson for statistical consultation. We also thank Glenn Shiell and 2 anonymous reviewers for their suggested improvements to the manuscript. This study was supported by the Swedish International Development Agency (Sida) and the Western Indian Ocean Marine Science Association (WIOMSA).

\section{LITERATURE CITED}

Andrew NL, Mapstone BD (1987) Sampling and the description of spatial patterns in marine ecology. In: Barnes $\mathrm{H}$, Barnes M (eds) Oceanography and marine biology: an 
annual review. Aberdeen University Press, Aberdeen, p 39-90

Bellchambers LM, Meeuwig JJ, Evans SN, Legendre P (2011) Modelling habitat associations of 14 species of holothurians from an unfished coral atoll: implications for fisheries management. Aquat Biol 14:57-66

Boström C, Pittman SJ, Simenstad C, Kneib RT (2011) Seascape ecology of coastal biogenic habitats: advances, gaps and challenges. Mar Ecol Prog Ser 427:191-217

Byrne M, Smoothey A, Hogget A, Uthicke S (2004) Population biology of shallow water holothuroids and ophiuroids from Rain Island and Moulter Cay, northern Great Barrier Reef. In: Heizeller T, Nebelsick JH (eds) Proc 11th Int Echinoderm Conf. Taylor \& Francis, London, p 165-169

Chao SM, Chen CP, Alexander PS (1994) Reproduction and growth of Holothuria atra (Echinodermata: Holothuroidea) at two contrasting sites in southern Taiwan. Mar Biol 119:565-570

Conand C (1989) Les holothuries aspidochirotes du lagon de Nouvelle-Calédonie: Biologie, écologie et exploitation. Etudes et thèses ORSTOM, Paris

Conand C (2008) Population status, fisheries and trade of sea cucumbers in Africa and the Indian Ocean. In: ToralGranda V, Lovatelli A, Vasconcellos M (eds) Sea cucumbers. A global review of fisheries and trade. FAO Fish Aquac Tech Pap 516:143-193

Conand C, Byrne M (1993) Recent evolution of the world fisheries for sea cucumbers. Mar Fish Rev 55:1-13

Conand C, Chardy P (1985) Are the aspidochirote holothurians of the New Caledonian lagoon good indicators of the reefal features? In: Proc 5th Int Coral Reef Congr, Vol 5. Antenne Museum-EPHE, Moorea, Tahiti, p 291-296

Conand C, Mangion P (2002) Sea cucumbers on La Reunion Island fringing reefs: diversity, distribution, abundance and structure of the populations. SPC Bêche-de-mer Info Bull 17:27-33

Conand C, Muthiga N (eds) (2007) Commercial sea cucumbers: a review for the Western Indian Ocean. WIOMSA Book Series No. 5, Nairobi

Conand C, Dinhut V, Quod JP, Rolland R (2005) Sea cucumber inventory in Mayotte, southwest Indian Ocean. SPC Bêche-de-mer Info Bull 22:19-22

Crowder L, Norse E (2008) Important insights for marine ecosystem-based management and marine spatial planning. Mar Policy 32:772-778

Desurmont A (2003) Papua New Guinea sea cucumber and beche-de-mer identification cards. SPC Bêche-de-mer Info Bull 18:8-14

Dissanyake DCT, Stefansson G (2012) Habitat preference of sea cucumbers: Holothuria atra and Holothuria edulis in the coastal waters of Sri Lanka. J Mar Biol Assoc UK 92:581-593

Dixon WJ, Massey FJ Jr (1969) Introduction to statistical analysis. McGraw-Hill, Tokyo

Dzêroski S, Drumm D (2003) Using regression trees to identify the habitat preference of the sea cucumber (Holothuria leucospilota) on Rarotonga, Cook Islands. Ecol Modell 170:219-226

English S, Wilkinson C, Baker V (eds) (2003) Survey manual for tropical marine resources, 2nd edn. ASEAN-Australian Marine Science Project, Living Coastal Resources, AIMS, Townsville

Eriksson H, de la Torre-Castro M, Eklöf J, Jiddawi N (2010) Resource degradation of the sea cucumber fishery in
Zanzibar, Tanzania: a need for management reform. Aquat Living Resour 23:387-398

Field JG, Clarke KR, Warwick RM (1982) A practical strategy for analysing multispecies distribution patterns. Mar Ecol Prog Ser 8:37-52

Friedman K, Purcell S, Bell J, Hair C (2008) Sea cucumber fisheries: a manager's toolbox. Monograph Series 135, Australian Centre for International Agricultural Research (ACIAR), Canberra

Friedman K, Eriksson H, Tardy E, Pakoa K (2011) Management of sea cucumber stocks: patterns of vulnerability and recovery of sea cucumber stocks impacted by fishing. Fish Fish 12:75-93

Gillanders BM, Albe KW, Brown JA, Eggleston DB, Sheridan PF (2003) Evidence of connectivity between juvenile and adult habitats for mobile marine fauna: an important component of nurseries. Mar Ecol Prog Ser 247:281-295

- Gratwicke B, Speight MR (2005) The relationship between fish species richness, abundance and habitat complexity in a range of shallow tropical marine habitats. J Fish Biol 66:650-667

Hamel JF, Conand C, Pawson DL, Mercier A (2001) The sea cucumber Holothuria scabra (Holothuroidea: Echinodermata): its biology and exploitation as beche-de-mer. Adv Mar Biol 41:129-223

Johnson MP, Frost NJ, Mosley MWJ, Roberts MF, Hawkins SJ (2003) The area independent effects of habitat complexity on biodiversity vary between regions. Ecol Lett 6: 126-132

Kinch J, Purcell S, Uthicke S, Friedman K (2008) Population status, fisheries and trade of sea cucumbers in the western Central Pacific. In: Toral-Granda V, Lovatelli A, Vasconcellos M (eds) Sea cucumbers. A global review of fisheries and trade. FAO Fish Aquac Tech Pap 516:7-55

MAD (Madagascar et Dependances) (1916) Administrative report written by the governor of Mayotte the 31th December 1916. MAD 2D73, Archives Nationales d'Outre-Mer, Antananarivo

Massin C, Doumen C (1986) Distribution and feeding of epibenthic holothuroids on the reef flat of Laing Island (Papua New Guinea). Mar Ecol Prog Ser 31:185-195

Massin C, Uthicke S, Purcell SW, Rowe FWE, Samyn Y (2009) Taxonomy of the heavily exploited Indo-Pacific sandfish complex (Echinodermata: Holothuriidae). Zool J Linn Soc 155:40-59

Mulochau T, Conand C (2008) Holothurians and other echinoderms of the Glorieuses Islands (Scattered Islands of the Indian Ocean). SPC Bêche-de-mer Info Bull 28: 34-39

> Nagelkerken I, van der Velde G, Gorissen MW, Meijer GJ, van't Hof T, den Hartog C (2000) Importance of mangroves, seagrass beds and the shallow coral reef for important reef fishes, using a visual census technique. Estuar Coast Shelf Sci 51:31-44

Oksanen J (2009) Multivariate analysis of ecological communities in R: vegan tutorial. Available at: http:// cc.oulu.fi/ jarioksa/opetus/metodi/vegantutor.pdf (accessed 2 February 2010)

Oksanen J, Blanchet FG, Kindt R, Legendre P and others (2011) Package 'vegan'. Available at: http://vegan.rforge.r-project.org/ (accessed 20 September 2011)

Perry IR, Walters CJ, Boutillier JA (1999) A framework for providing scientific advice for the management of new and developing invertebrate fisheries. Rev Fish Biol Fish 9:125-150 
Pouget A (2004) Sea cucumber fisheries in the Mayotte reef system, Indian Ocean. SPC Bêche-de-mer Info Bull 19: 35-38

Pouget A (2005) Abundance and distribution of holothurians on the fringing reef flats of Grande Terre, Mayotte, Indian Ocean. SPC Bêche-de-mer Info Bull 21:22-26

Prefecture de Mayotte (2004) Portant interdiction de l'exploitation des holothuries sur le territoire de la Collectivité Départemental de Mayotte. Arrete No. 32 SG/DAF 12004, Direction de l'Agriculture et de la Fôret, Mayotte

Purcell SW (2010) Managing sea cucumber fisheries with an ecosystem approach. FAO Fish Aquac Tech Pap 520

Purcell SW, Gossuin H, Agudo NN (2009) Status and management of the sea cucumber fishery of la Grande Terre, New Caledonia. Programme ZoNéCo. WorldFish Center Studies and Reviews No.1901. The WorldFish Center, Penang

Purcell S, Mercier A, Conand C, Hamel JF, Toral-Granda MV, Uthicke S (2011) Sea cucumber fisheries: global analysis of stocks, management measures and drivers of overfishing. Fish Fish doi:10.1111/j.1467-2979.2011. 00443.x

Quinn GP, Keough MJ (2002) Experimental design and data analysis for biologists. Cambridge University Press, Cambridge

R Development Core Team (2008) R: a language and environment for statistical computing. R Foundation for Statistical Computing, Vienna. www.R-project.org

Sale PF, Cowen RK, Danilowicz BS, Jones GP and others (2005) Critical science gaps impede use of no-take fishery reserves. Trends Ecol Evol 20:74-80

Samyn Y, Tallon I (2005) Zoogeography of the shallow-water holothuroids of the western Indian Ocean. J Biogeogr 32: 1523-1538

Samyn Y, VandenSpiegel D, Massin C (2005) Sea cucumbers of the Comoros Archipelago. SPC Bêche-de-mer Info Bull 22:14-18

Samyn Y, VandenSpiegel D, Massin C (2006) Taxonomie des holothuries des Comores. Abc Taxa vol 1: i-iii. www.abctaxa.be/downloads/volume-1-taxonomie-desholothuries-des-comores

Schneider K, Silverman J, Woolsey E, Eriksson H, Byrne M, Caldeira K (2011) Potential influence of aspidochirotid sea cucumbers on coral reef $\mathrm{CaCO}_{3}$ budget: a case study at One Tree Reef. J Geophys Res 116:G04032, doi: 10.1029/2011JG001755

Editorial responsibility: James McClintock, Birmingham, Alabama, USA
Shiell G (2004) Field observations of juvenile sea cucumbers. SPC Bêche-de-mer Info Bull 20:6-11

> Shiell GR, Knott B (2008) Diurnal observations of sheltering behaviour in the coral reef sea cucumber Holothuria whitmaei. Fish Res 91:112-117

Shiell GR, Knott B (2010) Aggregations and temporal changes in the activity and bioturbation contribution of the sea cucumber Holothuria whitmaei (Echinodermata: Holothuroidea). Mar Ecol Prog Ser 415:127-139

Shiell GR, Uthicke S (2006) Reproduction of the commercial sea cucumber Holothuria whitmaei [Aspidochirotoda: Holothuroidea] in the Pacific and Indian Ocean regions of Australia. Mar Biol 148:973-986

Slater MJ, Jeffs AG (2010) Do benthic sediment characteristics explain the distribution of juveniles of the depositfeeding sea cucumber Australostichopus mollis? J Sea Res 64:241-249

Tuya F, Hernández JC, Clement S (2006) Is there a link between type of habitat and the patterns of abundance of holothurians in shallow rocky reefs? Hydrobiologia 571: 191-199

Uthicke S (1999) Sediment bioturbation and impact of feeding activity of Holothuria (Halodeima) atra and Stichopus chloronotus, two sediment feeding holothurians, at Lizard Island, Great Barrier Reef. Bull Mar Sci 64: 129-141

Uthicke S, Benzie JAH (2000) Effect of bêche-de-mer fishing on densities and size structure of Holothuria nobilis [Echinodermata: Holothuroidea] populations on the Great Barrier Reef. Coral Reefs 19:271-276

Uthicke S, Karez R (1999) Sediment patch selectivity in tropical sea cucumbers (Holothuroidea: Aspidochirotida) analysed with multiple choice experiments. J Exp Mar Biol Ecol 236:69-87

> Uthicke S, Welch D, Benzie JAH (2004) Slow growth and lack of recovery in overfished holothurians on the Great Barrier Reef: evidence from DNA fingerprints and repeated large-scale surveys. Conserv Biol 18: 1395-1404

> Wilson SK, Graham NAJ, Polunin NVC (2007) Appraisal of visual assessment of habitat complexity and benthic composition on coral reefs. Mar Biol 151:1069-1076

- Wolkenhauer SM, Uthicke S, Burridge C, Skewes T, Pitcher R (2010) The ecological role of Holothuria scabra (Echinodermata: Holothuoroidea) within subtropical seagrass beds. J Mar Biol Assoc UK 90:215-223

Submitted: November 29, 2011; Accepted: February 2, 2012 Proofs received from author(s): April 16, 2012 